専門医症例報告

\title{
舌右側亜全摘および高度顎堤吸収を伴う上下無歯顎補綴症例
}

白石 康博

\section{A Case Report of Prosthodontic Treatment for Edentulous Patients with Severe Alveolar Ridge and Right Tongue Sub-total Extirpation}

\author{
Yasuhiro Shiraishi
}

\begin{abstract}
抄 録
症例の概要 : 患者は 73 歳の女性。舌右側亜全摘および上下総義歯不適合による咀嚼障害，審美不良を主 訴に来院した。機能回復を目的とし，マウスボリュームおよび顔貌の回復を考慮した治療用義歯を使用し， 義歯の支持，筋平衡，維持，咬合平衡を獲得した新義歯を製作した。

考察：マウスボリュームを適切に回復した治療用義歯の使用で，口腔周囲筋や舌と調和した形態を導き出 すばかりでなく，最大限の機能を引き出すことができたと考えられる.

結論：本症例では，舌右側亜全摘および高度顎堤吸収を伴う患者であったが，適切な治療用義歯を使用し たことにより審美性と口腔機能が回復し，現在まで良好に経過している。
\end{abstract}

和文キーワード

マウスボリューム，治療用義歯，研摩面形態，フラットテーブル，機能印象

\section{ABSTRACT}

Patient: A 73-year-old woman presented with the chief complaint of esthetic and chewing problems because of unstable dentures on both maxilla and mandibular, and right tongue sub-total extirpation. We made a treatment denture, which basically aimed at increased mouth volume and restore facial image to improve function. This resulted in improved stability of denture, oral muscles and bite.

Discussion: Using the treatment denture, the volume of the mouth was recovered and it is thought that the form harmonizes with the oral muscles and the tongue. The form is not only to be derived but also extracts the maximum function.

Conclusion: Using the treatment denture, the patient has regained oral function and progress has been satisfactory, even though, the patient has both less ridge and right tongue sub-total extirpation.

\section{Key words}

mouth volume, treatment denture, form of polished surface, flat table, functional impression registration 


\section{I. 緒言}

近年，高齢化が進み高度機能障害を呈する無歯顎患者 が増加している，今回，舌右側亜全摘および上下顎高度 顎堤吸収, 下顎位の不安定を伴う無歯顎患者の補綴治療 を行い，顔貌および機能が回復し良好な結果が得られた のでその概要を報告する.

\section{II. 症例の概要}

患者: 73 歳 (初診時)，女性.

初診：2007 年 2 月 8 日.

主訴：上下の入れ歯が合わず噛めない，笑ったときに 歯が見えない。

既往歴：約 50 年前に某大学病院にて舌癌の診断によ り舌右側严全摘および右側全䅡部郭清術を行った。その 後，定期検診において再発は認められない.

現病歴：約 25 年前に上下無歯顎となり総義歯を作製 した。しかしよく噛めず，その後数件の歯科医院で義歯 を新製したがどれも満足に使用することができなかっ た。今回，知人の紹介により当病院を受診.

現症：上顎顎堤は $5 \mid 5$ 相当部にかけて高度な顎堤吸 収およびフラビーガムを認めた。 下顎顎堤も歯槽骨およ び顎骨の高度な顎堤吸収を認め，オトガイ棘が高位とな りパノラマX X 線写真上でオトガイ孔が顎堤上に開口し ているのが確認できた (図 1)。旧義歯は支持, 維持不足, 咬合平面・人工歯排列の不正，リップサポート不足，舌 房の侵害, 煩側の死腔が認められた，上顎義歯粘膜面に は粘膜調整材が劣化した状態になっており，下顎義歯粘 膜面には義歯安定剤が常用されていた（図 2).

舌切除部位は舌右側側緑に限局しており, 移植等の皮 弁や瘢痕は認められなかった。また，舌運動に左右差が あるものの発音障害も認められなかった。しかし，咀嚼 機能検査において咀嚼スコア ${ }^{1)}: 7.7$ であり, 右側では ほとんど咀嚼していない状態であった，唾液の量，粘稠 度はともに正常であった。

診断：上下顎義歯不適合および舌右側亜全摘による咀 嚼障害・審美障害。

治療方針：マウスボリュームおよび顔貌の回復を考慮 し, 治療用義歯を用い感覚入力系 - 中枢処理系 - 運動出 力系の再構築を行い, 支持 - 筋平衡 - 維持 ・ 咬合平衡 ${ }^{2)}$ を獲得する。すなわち，咬合高径の回復とともに煩側の 死腔を封鎖，煩筋の機能を向上させるための幅，舌房の 回復また舌亜全摘部位の研磨面形態を舌機能をサポート するように付与し機能的維持力を獲得する．患者にはリ
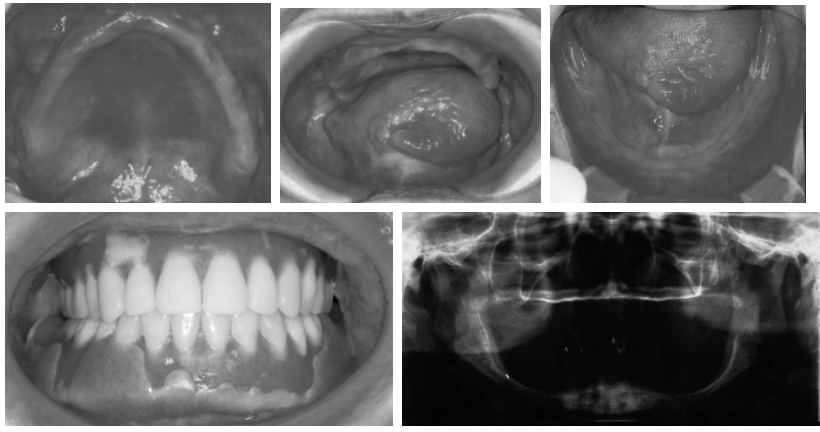

図 1 Intraoral views and panoramic radiograph at the first examination

初診時の口腔内写真とパノラマX 線画像
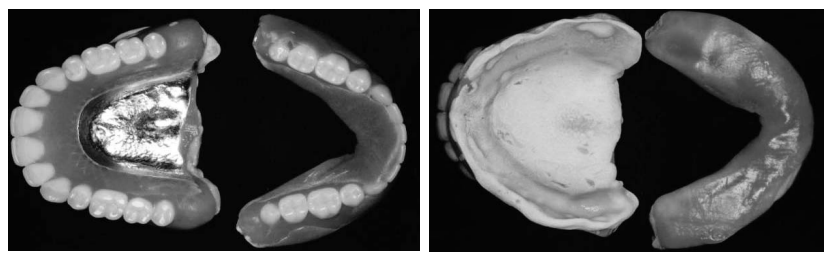

図 2 Existing dentures at the first examination 初診時に使用していた義歯

ハビリ・トレーニングを説明し機能時の義歯の安定を図 り，新義歯にはこの治療用義歯形態をそのまま再現する こととした.

\section{III，治療内容と経過}

はじめに治療用義歯作製のため，アルジネート印象材

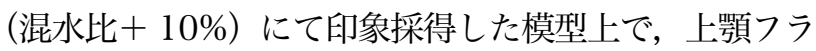
ビーガム部を一層リリーフ後，モデリングコンパウンド を均等に $1.5 \mathrm{~mm}$ ライニングした個人トレーにて選択 加圧印象を行った。これにより，咀嚼粘膜部の支持領域 と, 辺縁部の内側弁・外側弁 ${ }^{3)}$ による維持形態を採得 した.

通法に従い咬合平面の決定後，垂直的顎間関係は上下 口唇（赤唇部）の面積の一致, 口角の㱀 $1 \sim 2 \mathrm{~mm}$, 矢状鼻唇角 $95^{\circ}$, Wills 法等を参考に, 旧義歯より鼻下 点 - オトガイ間で $4 \mathrm{~mm}$ 拳上した. 水平的顎間関係は 毎秒 3 回のライトタッピングおよび燕下を利用し咬合 採得を行ったが，下顎位は不安定で 1 点に収束しなか つた。

また，上下対向関係は矢状面で難症例を示す前方開離 型であった（図 3)。人工歯は顎堤の舌側歯肉縁残遺を 基準に，もとあった歯の位置（歯槽頂より煩側より）に 排列，下顎位の決定を治療用義歯上で行うために下顎臼 


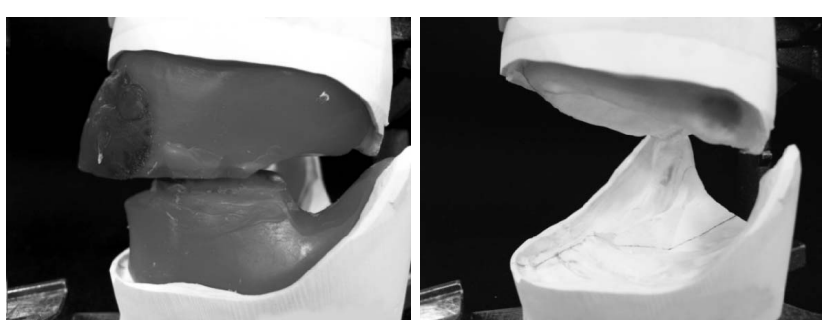

図 3 Maxillomandibular interocclusal relation 上下対向関係

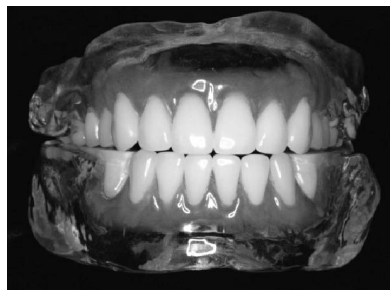

図 4 Treatment denture 治療用義歯
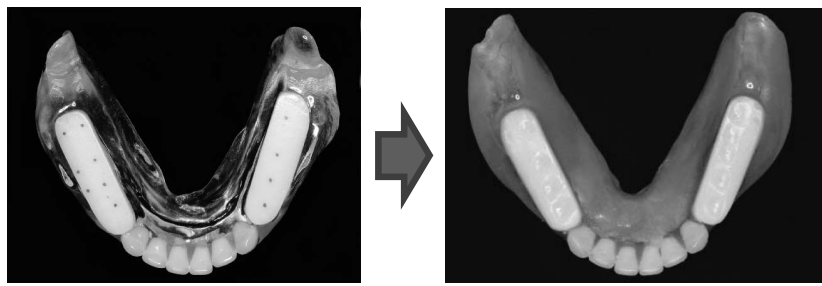

図 5 A track of flat table フラットテーブルの軌跡
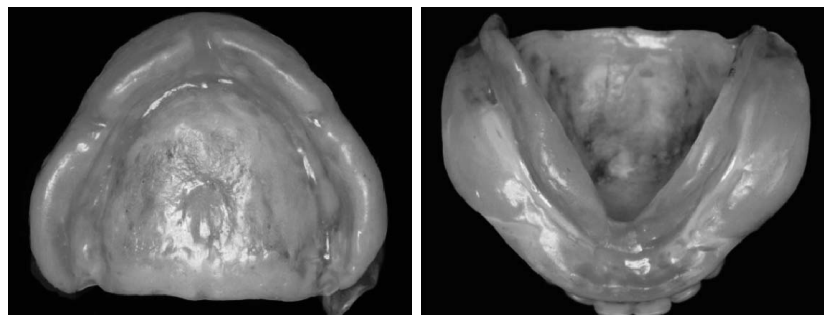

図 6 Functional impression registration 機能印象
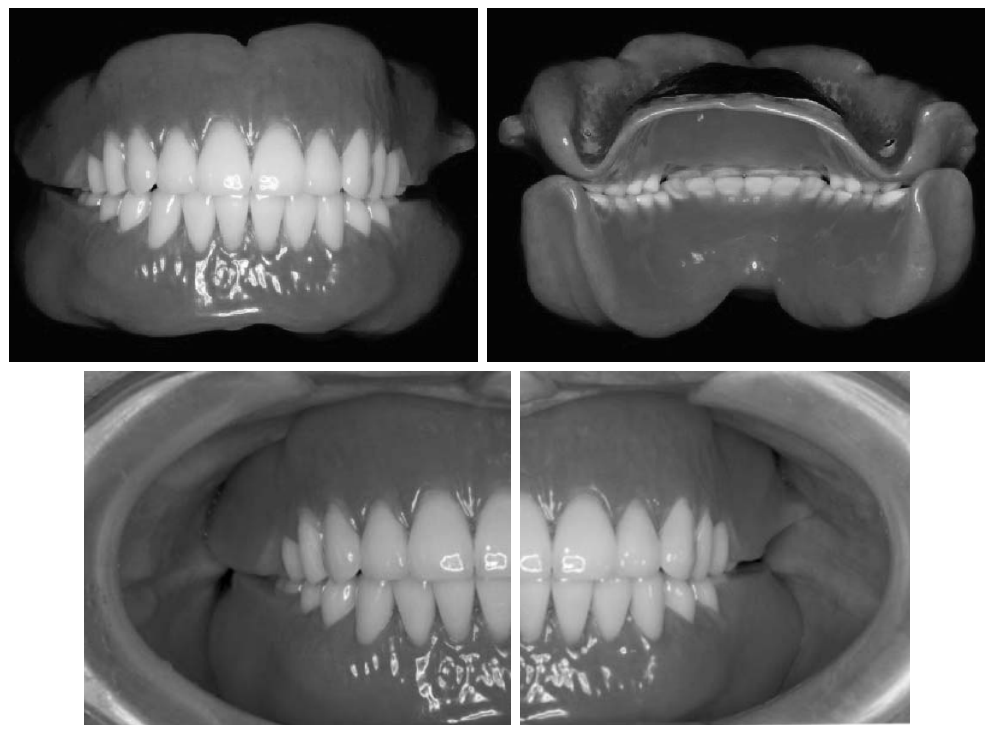

図 7 New dentures 最終義歯

歯にはフラットテーブルを用いた。しかし，この患者の 対向関係の場合，フラットテーブルの排列のように咬合 平面に対して平行かつフラットに排列すると，上下顎と もに咬合時, 前方への推進現象を引き起こすこととなる ため, 義歯の前後方向での維持力と筋平衡が必要になる. そこで，義歯試適時に煩舌側にシリコーン印象材を注入 し, 嚥下による機能圧によりリップサポートの形態, 煩 側の死腔および舌房の形態を印記した ${ }^{4)}$ 。㚘頁側研磨面は 煩筋の 2 層構造のうち粘膜側の深層の筋線維走行に調
和した形態を，また舌側研磨面は舌房を侵害しないよう 通常凹面形態を付与するが右側舌側のみ印記された通り 凸面形態とし，口腔周囲筋に調和した形態を付与した。 この形態により，口輪筋，煩筋，舌の機能的維持力を獲 得し，上下顎義歯の三次元的安定を図った（図 4).

治療用義歯装着後，患者には 1）毎秒 3 回のライト夕 ッピング，2）左右でしっかり，ゆっくり咀嚼し長く嬹 下する，3）新聞, 雑誌を大きな声を出して読む，4）適 度な直射日光下での運動，5）顎堤粘膜の水による冷却 


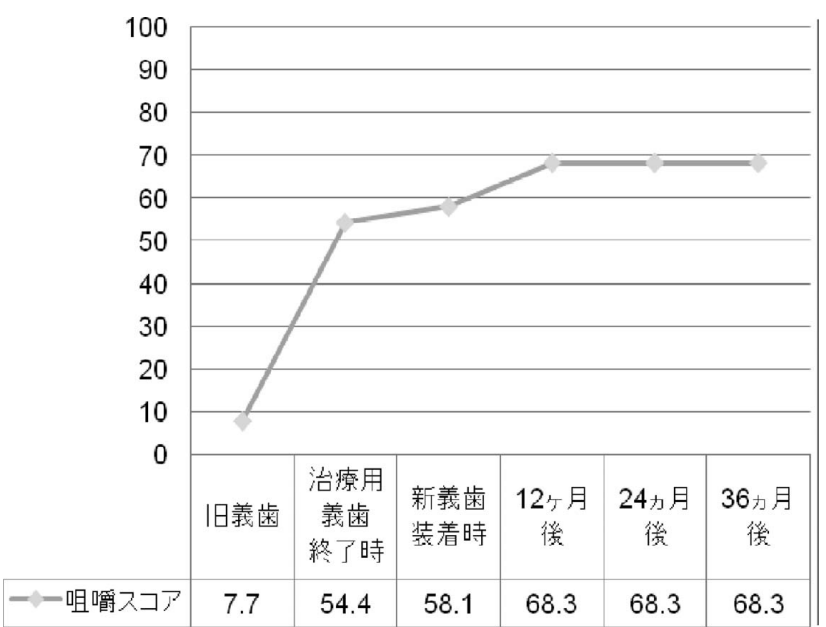

図 8 Masticatory score and its changes over time 咀嚼スコアの推移

と指によるマッサージを行うよう指導した，咀嚼筋群の 衰えから当初粘膜の痛みは出なかったが，咀嚼機能の向 上に伴い義歯辺縁部に痛みが出てきたため, 主に辺縁と 研磨面を粘膜調整材にて調整した。

治療用義歯装着 13 週後のフラットテーブルには明確 な压痕か形成され，左右ともにほぼ均等であり，下顎位 および義歯の安定が読み取れる（図 5)。また，装着当 初マウスボリュームの回復に伴い固有口腔が増加し発音 障害が認められたが，口蓋㱀譬部の調整とリハビリ・ト レーニングおよび義歯の安定化とともに改善した。

この状態で，動的印象材にて機能印象を行い，さらに シリコーン印象材により煩側の研磨面形態を採得し，新 義歯を製作した（図 6，7)。咬合および人工歯の選択は 前方離開型の顎堤条件およびフラットテーブルの圧痕に 適応させるため, 前歯バイオブレンド陶歯, 臼歯コンデ ユロフォームを使用し，ゲルバーテクニックによるレデ ユースドオクルージョンを付与した。

新義歯装着後, 咀嚼スコアにおいても旧義歯と比較し 顕著な増加 $(7.7 \rightarrow 58.1)$ を示した（図 8). その後 1 力月, 以降 3 力月間隔でメインテナンスを行っているが, 1 年半後, 義歯を落として 1 人工歯の切緑の一部が破折 したのみで, 以後現在 3 年経過したが顎位の偏位もな く良好に経過している(図9).

\section{IV. 考 察}

本症例において，マウスボリュームを適切に回復した 治療用義歯の使用で，支持・筋平衡・維持・咬合平衡が 確立し下顎位が安定した。これにより口腔周囲筋や舌と 調和した形態を導き出すばかりでなく, 最大限の機能を

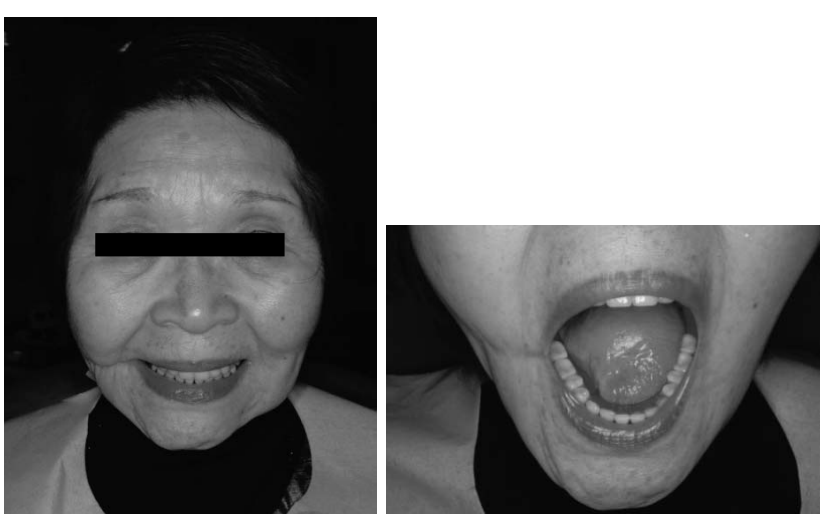

図 9 Face and intraoral view at 3 years after prosthetic treatment

補綴終了 3 年経過時の顔貌および口腔内写真

引き出すことができるようになったと思われる。また， 中枢神経系に対し正しい感覚入力が伝達され，それによ り適切な運動制御を引き出すこととなり, 口腔機能が改 善したと考えられる。

\section{V. 結 論}

本症例では，舌右側亜全摘および高度顎堤吸収を伴う 下顎位の不安定な患者であったが，三次元的にマウスボ リュームを回復した治療用義歯を使用することにより， 形態と機能が調和し現在まで良好な経過が得られた。

\section{文献}

1）平井敏博. 健康科学を基盤とした歯科補綴学の構築. 咬合・ 咀嚼が創る健康長寿の実現へ向けて。補綴誌 2007; 51: 691-698.

2）Watt DM, MacGregor AR（小林義典，鳥居健吾，田中 武) . Designing Complete Dentures（コンプリート デンチャーの設計。東京：医歯薬出版；1979，4-352.), 1976.

3) Uhlig H (小山正宏). Zahnersatz für zahnlose (ウー リッ七総義歯学．東京：クインテッセンス出版；1982, 19-26.), 1970.

4） Beresin VE, Schiesser FJ（柳田尚三，小林義典，鳥居 健吾). The Neutral Zone in Complete Dentures (二 ュートラルゾーン総義歯学, その理論と実際。東京 : 医 歯薬出版；1976, 144-152.),1973.

著者連絡先：白石 康博 于 $101-8310$ 東京都千代田区神田駿河台 1-8-13

Tel: 03-3219-8144

Fax: 03-3219-8350

E-mail: shiraishi@dent.nihon-u.ac.jp 